\title{
JURNAL LESTIATAN LINGEUNGAN

\section{HUBUNGAN POLA ASUH DAN PEMBERIAN ASI EKSKLUSIF DENGAN GIZI KURANG PADA BALITA DI WILAYAH KERJA PUSKESMAS NAMBO KOTA KENDARI (STUDI KASUS SUKU BAJO DAN NON BAJO)}

\author{
The Relationship of Foster Care Pattern and Exclusive Breastfeeding with \\ Malnutrition in Toddlers in The Working Area of Public Health Center \\ of Nambo in Kendari City (Case Study Of Bajo And Non Bajo Tribe)
}

\author{
Rika Saputri Musaruddin ${ }^{1}$, La Ode Muhamad Sety ${ }^{2 *}$, Yasnani ${ }^{3}$ \\ Jurusan Kesehatan Masyarakat,Fakultas Kesehatan Masyarakat,Universitas Haluoleo \\ (rikasaputrimusaaa@gmail.com', setyuho@gmail.com², yasnani78@yahoo.com³)
}

\begin{tabular}{l}
\hline INFO ARTIKEL \\
\hline Diterima: \\
Juli 2020 \\
Dipublikasi: \\
Oktober 2020 \\
\hline Kata Kunci: \\
pola asuh, asi \\
eksklusif, gizi kurang \\
\hline Keywords: \\
parenting, exclusive \\
breastfeeding, \\
malnutrition \\
\hline *Penulis \\
Korespondensi \\
Email: \\
setyuho@gmail.com \\
(La Ode Muhamad \\
Sety)
\end{tabular}

\begin{abstract}
Abstrak
Malnutrisi merupakan kontributor utama beban penyakit, dengan lebih dari setengah kematian global pada anak-anak di bawah 5 tahun disebabkan oleh kurang gizi, yang sebagian besar di negara-negara berpenghasilan rendah dan menengah, termasuk Indonesia dan kekurangan gizi global adalah prioritas utama dari target WHO. Tujuan Pembangunan Berkelanjutan PBB (SDG) juga menetapkan target dengan tujuan menghilangkan kekurangan gizi pada tahun 2030. Tujuan dari penelitian ini adalah untuk mengetahui hubungan pola asuh dan pemberian asi eksklusif dengan gizi kurang pada balita di wilayah kerja Puskesmas Nambo Kota Kendari (studi kasus suku bajo dan non bajo). Metode pengambilan sampel dengan sistem purposive sampling. Hasil penelitian menunjukkan bahwaAda hubungan antara pola asuh dengan gizi kurang pada balita Suku Bajo dan Non Bajo di wilayah kerja Puskesmas Nambo Kota Kendari tahun 2019 dengan p-Value 0,039 dan ada hubungan antara pemberian ASI eksklusif dengan gizi kurang pada balita Suku Bajo dan Non Bajo di wilayah kerja Puskesmas Nambo Kota Kendari tahun 2019 dengan p-value 0,000. Kesimpulan ialah ada hubungan pola asuh dan pemberian asi eksklusif dengan gizi kurang pada balita di wilayah kerja Puskesmas Nambo Kota Kendari tahun 2019 (studi kasus suku bajo dan non bajo).
\end{abstract}

\footnotetext{
Abstract

Malnutrition is a major contributor to the burden of disease, with more than half of global deaths in children under 5 years of age caused by malnutrition, mostly in low-and middleincome countries, including Indonesia and global malnutrition being a top priority of who's target. The UN Sustainable Development Goals (SDGs) also set targets with the aim of eliminating malnutrition by 2030. The purpose of this study was to find out the relationship between foster care and exclusive breastfeeding patterns with malnutrition in toddlers in the working area of public health center of Nambo (case study of bajo and non bajo tribes). This study used sampling method with purposive sampling system. The results showed that there wass a relationship between foster care patterns and malnutrition in bajo and non bajo toddlers in the working area of Puskesmas Nambo Kota Kendari with p-value 0.039 and there is a relationship between exclusive breastfeeding and malnutrition in Bajo and Non Bajo toddlers in the working area of public health center of Nambo Kendari city with $p$-value 0.000 . The conclusion was that there was a relationship between foster care and exclusive breastfeeding with malnutrition in toddlers in the working area of public health center of Nambo Kendari city (case studies of bajo and non bajo tribes).
} 


\section{JURNAL REGEHATAN LINGKUNGAN

\section{PENDAHULUAN}

Malnutrisi merupakan kontributor utama beban penyakit, dengan lebih dari setengah kematian global pada anak-anak di bawah 5 tahun disebabkan oleh kurang gizi, yang sebagian besar di negara-negara berpenghasilan rendah dan menengah, termasuk Indonesia dan kekurangan gizi global adalah prioritas utama dari target WHO. Untuk memacu tindakan dan memantau kemajuan, WHO membentuk enam indikator malnutrisi yang akan dicapai pada tahun 2025. Tujuan Pembangunan Berkelanjutan PBB (SDG) juga menetapkan target dengan tujuan menghilangkan kekurangan gizi pada tahun 2030 (1).

$$
\begin{gathered}
\text { World Health } \\
\text { melaporkanization } \\
\text { bahwa }
\end{gathered}
$$
diperkirakan terkait dengan 2,7 juta kematian anak setiap tahun atau $45 \%$ dari semua kematian anak akibat kekurangan gizi. Secara global Pada tahun 2016, 155 juta anak dibawah 5 tahun diperkirakan mengalami kekurangan gizi dan pada tahun 2017 diperkirakan 22,2 \% atau 150,8 juta anak-anak dibawah 5 tahun mengalami kekurangan gizi. Di Asia sebanyak 83,6 juta anak, Amerika Utara sebanyak 0,5 juta anak, Amerika Latin dan Karibia sebanyak 5,1 juta anak, Afrika 58,7 juta anak dan Oceania sebanyak 0,5 juta anak mengalami kekurangan gizi (2).

Masalah gizi masih merupakan masalah kesehatan masyarakat di Indonesia maupun negara berkembang.Kekurangan gizi pada umumnya terjadi pada balita, karena pada umur tersebut anak mengalami pertumbuhan yang pesat.Balita termasuk kelompok yang rentan gizi di suatu kelompok masyarakat dimana masa itu merupakan masa peralihan mulai saat mulai mengikuti pola makan orang dewasa (3).

Faktor-faktor yang mempengaruhi status gizi anak balita dan penyebab kurang gizi pada balita di masyarakat yaitu: penyebab langsung dan tidak langsung. Makanan dan penyakit dapat secara langsung menyebabkan gizi kurang. Penyebab tidak langsung ada tiga yaitu: ketahanan pangan, pola pengasuhan anak, dan pelayanan kesehatan dan lingkungan. Pola pengasuhan yang berupa sikap dan perilaku ibu sangat pening terhadap tumbuh kembang anak. Cara pemberian makan maupun pengetahuan tentang jenis makanan yang harus diberikan sesuai umur dan kebutuhan serta memberikan kasih sayang dan sebagainya merupakan komponen yang perlu diketahui dari masing-masing orang tua (4).

Riset kesehatan dasar tahun 2018 status gizi anak dibawah lima tahun (balita) berdasarkan prevalensi status gizi $(B B / U)$ di Indonesia adalah yang menderita gizi kurang sebesar $13,8 \%$ bahkan masih terdapat gizi buruk yaitu sebesar 3,9\%, angka gizi kurang tersebut tercermin pada masih tingginya prevalensi balita yang mengalami status gizi $(T B / U)$ yaitu pendek sebesar 19,3\% dan sangat pendek sebesar $11,5 \%$ sedangkan prevalensi status gizi (BB/TB) di indonesia adalah kurus sebesar 6,7\% dan sangat kurus sebesar 3,5\% (5).

Data Riskesdas tahun 2018 menunjukkan bahwa Provinsi Sulawesi Tenggara masuk dalam 10 besar angka gizi kurang dari 34 provinsi di Indonesia. Secara umum jumlah kasus gizi kurang di Provinsi Sulawesi Tenggara pada tahun 2017 adalah sebesar 220 kasus. Wilayah kabupaten/kota di Sulawesi Tenggara yang angaka kasus gizi kurang bahkan gizi buruk nya diatas 10 kasus terdapat di wilayah Kabupaten Muna, Kabupaten Buton, Kabupaten Konawe, Kabupaten Wakatobi, Kabupaten Konawe Selatan, Kabupaten Bombana, Kabupaten Kolaka Utara bahkan Kota Kendari pun masuk dalam wilayah tersebut yang merupakan ibu kota provinsi Sulawesi Tenggara (6).

Data gizi kurang di Kota Kendari tahun 2018 sebanyak 492 kasus. Angka kurang gizi yang tertinggi terdapat di Puskesmas Puwatu 129 dengan balita yang ditimbang sebanyak 1165 dan yang terendah terdapat di Puskesmas Mokoau, Mekar dan Kemaraya dengan angka gizi kurang o kasus. Puskesmas Nambo masuk dalam 10 besar angka kurang gizi di Kota Kendari sebanyak 22 kasus dengan 411 balita yang ditimbang. Puskesmas Nambo juga berada tepat di wilayah pesisir Kota Kendari dan mempunyai masyarakat suku bajo terbanyak di kota kendari yaitu di kelurahan Petoaha sebanyak 503 jiwa, dibandingkan dengan puskesmas-puskesmas yang berada di wilayah Kota Kendari lainnya (7).

Pemilihan masyarakat Bajo sebagai obyek penelitian didasarkan atas beberapa keunikan diantaranya, masyarakat Bajo tidak memiliki pendidikan yang memadai sebab mereka tidak mementingkan pendidikan formal dan pada umumnya anak-anak masyarakat Bajo 


\section{JURNAL LESTELATAN ITGEUNGAN \\ UNIV. HALU OLEO \\ (JKL - UHO)}

menempuh pendidikan pada jenjang pendidikan dasar saja sebagai konsekuensinya masyarakat Bajo adalah kelompok masyarakat yang buta huruf, masyarakat Bajo juga tidak terlalu fasih dalam berbahasa indonesia sehingga menyulitkan untuk komunikasi. Maka dari keunikan tersebut peneliti tertarik untuk menjadikan masyarakat suku Bajosebagai objek penelitian untuk membandingkan dengan masyarakat suku Non Bajo.

\section{METODE}

Penelitian ini menggunakan penelitian komparatif dengan desain penelitian croos sectional study. Penelitian ini di lakukan pada bulan Desember-Januari di wilayah kerja Puskesmas Nambo dengan populasi semua balita yang berada di wilayah kerja Puskesmas Nambo yang berumur 12-59 bulan. Penentuan besar sampel pada dua kelompok independen dengan uji hipotesis Sugiyono. Analisis data dalam penelitian ini terdiri dari dua analsisi, pertama analisisunivariat di lakukan untuk mendapatkan gambaran umum variabel yang di teliti dilakukan dengan mendeskripsikan masing-masing variabel dengan analisis dan distribusi frekuensi dan kedua analisis bivariat digunakan untuk mengetehui ada atau tidaknya hubungan sanitasi lingkungan dan higiene perorangan dengan kejadian diare pada balita dalam analisis ini dilakukan dengan pengujian statistik yaitu dengan uji chi-square pada taraf kepercayaan $95 \%$.

HASIL

Hubungan Pola Asuh dengan Gizi Kurang pada Suku Bajo dan Non Bajo di Wilayah Kerja Puskesmas Nambo

Tabel 1. Distribusi Responden Menurut Pola Asuh di Wilayah Kerja Puskesmas Nambo

\begin{tabular}{ccc}
\hline \multirow{2}{*}{ Pola Asuh } & Jumlah & \\
\cline { 2 - 3 } & $\mathbf{n}$ & $\%$ \\
\hline Memenuhi syarat & 77 & 96,2 \\
\hline Tidak memenuhi syarat & 3 & 3,8 \\
\hline Total & $\mathbf{8 0}$ & $\mathbf{1 0 0}$ \\
\hline
\end{tabular}

Tabel 1 menunjukkanbahwa dari 80 responden yang diteliti yang memenuhi syarat yaitu sebanyak 77 responden (96,2\%), sedangkan responden yang tidak memenuhi syarat yaitu sebanyak 3 responden (3,8\%).
Tabel 2. Hubungan Pola Asuh dengan Gizi Kurang pada Suku Bajo dan Non Bajo di Wilayah Kerja Puskesmas Nambo

\begin{tabular}{|c|c|c|c|c|c|c|c|}
\hline \multirow{3}{*}{ Pola Asuh } & \multicolumn{4}{|c|}{ Gizi kurang } & \multirow{2}{*}{\multicolumn{2}{|c|}{ Jumlah }} & \multirow{3}{*}{$\rho$-value } \\
\hline & \multicolumn{2}{|c|}{ Bajo } & \multicolumn{2}{|c|}{ Non Bajo } & & & \\
\hline & $\mathbf{n}$ & $\%$ & $\mathbf{n}$ & $\%$ & $\mathbf{n}$ & $\%$ & \\
\hline $\begin{array}{c}\text { Memenuhi } \\
\text { syarat } \\
\text { Tidak }\end{array}$ & 37 & 92,5 & 40 & 100 & 77 & 96,2 & \\
\hline $\begin{array}{c}\text { memenuhi } \\
\text { syarat }\end{array}$ & 3 & 7,5 & 0 & 0 & 3 & 3,8 & 0,039 \\
\hline Total & 40 & 100 & 40 & 100 & 80 & 100 & \\
\hline
\end{tabular}

Tabel 2 menunjukkan bahwa pola asuh pada umumnya responden memenuhi syarat. Hal ini disebabkan karena responden Suku Bajo cenderung memenuhi syarat yaitu sebanyak 37 responden $(92,5 \%)$ sama dengan responden Non Bajo yangseluruhnya memenuhi syarat yaitu sebanyak 40 responden (100\%). Hasil analisis menggunakan $\alpha=0,05$ menunjukan perolehanp-Value 0,039 denganp-Value>0,05 maka $\mathrm{H}_{\mathrm{o}}$ ditolak yaitu ada hubungan antara pola asuh dengan gizi kurang pada masyarakat suku Bajo dan Non Bajo di wilayah kerja Puskesmas Nambo.

Hubungan Pemberian ASI Eksklusif Dengan Gizi Kurang pada Suku Bajo dan Non Bajo Di Wilayah Kerja Puskesmas Nambo

Tabel 3. Distribusi Responden Menurut Pemberian ASI Eksklusif di Wilayah Kerja Puskesmas Nambo

\begin{tabular}{ccc}
\hline \multirow{2}{*}{ Pemberian ASI Eksklusif } & \multicolumn{2}{c}{ Jumlah } \\
\cline { 2 - 3 } & $\mathbf{n}$ & $\%$ \\
\hline Ya & 34 & 42,5 \\
Tidak & 46 & 57,5 \\
\hline Total & $\mathbf{8 0}$ & $\mathbf{1 0 0}$ \\
\hline
\end{tabular}

Tabel 3 menunjukkan bahwa dari 80 responden yang diteliti yang memberikan ASI eksklusif sebanyak 36 responden (45\%), sedangkan responden yang tidak memberukan ASI eksklusif yaitu sebanyak 44 responden (55\%). 


\section{JURNAL REGEHATAN LINGKUNGAN

Tabel 4. Hubungan Pemberian ASI Eksklusif dengan Gizi Kurang pada Suku Bajo dan Non Bajo di Wilayah Kerja Puskesmas Nambo

\begin{tabular}{|c|c|c|c|c|c|c|c|}
\hline \multirow{3}{*}{$\begin{array}{l}\text { Pemberian } \\
\text { ASI Eksklusif }\end{array}$} & \multicolumn{4}{|c|}{ Gizi kurang } & \multirow{2}{*}{\multicolumn{2}{|c|}{ Jumlah }} & \multirow{3}{*}{$\rho$-value } \\
\hline & \multicolumn{2}{|c|}{ Bajo } & \multicolumn{2}{|c|}{ Non Bajo } & & & \\
\hline & $\mathbf{n}$ & $\%$ & $\mathbf{n}$ & $\%$ & $\mathbf{n}$ & $\%$ & \\
\hline $\begin{array}{c}\text { Memenuhi } \\
\text { syarat } \\
\text { Tidak }\end{array}$ & 8 & 20 & 26 & 65 & 34 & 42,5 & \\
\hline $\begin{array}{c}\text { memenuhi } \\
\text { syarat }\end{array}$ & 32 & 80 & 14 & 35 & 46 & 57,5 & 0,000 \\
\hline Total & 40 & 100 & 40 & 100 & 80 & 100 & \\
\hline
\end{tabular}

Tabel 4 menunjukkan bahwa pemberian ASI eksklusif dapat diketahui bahwa dari 80 responden (100\%) sebanyak 34 (42,5\%) memenuhi syarat dan $46 \quad(57,5 \%)$ tidak memenuhi syarat. Hal ini di sebabkan karena responden Suku Bajo cenderung tidak memenuhi syarat yaitu sebanyak 32 (80\%) responden, berbanding terbalik dengan responden Non Bajo yang memenuhi syarat sebanyak 26 (65\%) responden.Hasil analisis menggunakan $\alpha=0,05$ menunjukan perolehan $p$ Value 0,000 denganp-Value>0,05 maka $\mathrm{H}_{0}$ ditolak yaitu ada hubungan antara pemberian ASI eksklusif dengan gizi kurang pada masyarakat suku Bajo dan Non Bajo di wilayah kerja Puskesmas Nambo.

\section{PEMBAHASAN}

Hubungan Pola Asuh dengan Gizi Kurang pada Suku Bajo dan Non Bajo di Wilayah Kerja Puskesmas Nambo

Pola asuh balita adalah kemampuan keluarga dan masyarakat untuk menyediakan waktu, perhatian dan dukungan terhadap anak agar dapat tumbuh dengan sebaik-baiknya seara fisik, mental, dan sosial. Pola pengasuhan anak berupa sikap perlakuan ibu dalam hal kedekatannya dengan anak, memberikan makanan, merawat, menjaga kesehatan dan kebersihan, memberikan kasih sayang, dan sebagainya. Akan tetapi hasil penelitian ini tidak sesuai dengan teori diatas karena walaupun pola asuh ibunya cukup tetapi balita menderita penyakit infeksi sehingga balita kesulitan mencerna dan menelan makanan serta penyerapan zat gizi dalam tubuh terganggu (8).

Salah satu faktor yang berperan penting dalam status gizi balita adalah pola asuh. Pola asuh merupakan interaksi antara anak dan orang tua selama mengadakan kegiatan pengasuhan. mengasuh anak adalah mendidik, membimbing dan memelihara anak, mengurus makanan, minuman, pakaian, kebersihannya, atau pada segala perkara yang seharusnya diperlukannya, sampai batas bilamana si anak telah mampu melaksanakan keperluannya yang vital, seperti makan, minum, mandi dan berpakaian. Salah satu yang mempengaruhinya yaitu ibu, keadaan gizi di pengaruhi oleh kemampuan ibu menyediakan pangan yang cukup untuk anak serta pola asuh yang di pengaruhi oleh faktor pendapatan keluarga, pendidikan, prilaku dan jumlah saudara (9).

Pola pengasuhan anak dalam pemberian makan sehari-hari ditentukan oleh tingkat pendidikan ibu dan pengetahuan ibu tentang gizi balita. Sebagian besar kejadian gizi kurang dapat dihindari apabila ibu sebagai orang yang paling dekat dengan anak mempunyai pengetahuan yang cukup tentang gizi. Pengetahuan yang harus diketahui oleh seorang ibu adalah tentang kebutuhan gizi, cara pemberian makan, jadwal pemberian makan pada balita, sehingga akan menjamin anak dapat tumbuh dan berkembang dengan optimal (10).

Hasil analisis data secara statistik menunjukkan bahwa ada berhubungan pola asuh dengan gizi kurang pada balita suku Bajo dan Non Bajo di wilayah kerja Puskesmas Nambo Kota Kendari tahun 2019. Berdasakan hasil penelitian yang diperoleh secara langsung melalui wawancara dan pengisian kuisioner di wilayah kerja Puskesmas Nambo menunjukan bahwa dari 80 responden yang di teliti sebanyak 77 responden memenuhi syarat dan hanya 3 responden yang tidak memenuhi syarat.

Berdasarkan hasil penelitian, responden menyiapkan sendiri makanan yang akan di konsumsi oleh anaknya dalam tiga kali sehari, akan tetapii makanan yang di berikan hanya makanan pokok,lauk-pauk dan sayuran bahkan dari sebagian responden juga biasanya hanya memberikan anaknya makanan pokok dan laukpauknya saja tidak termasuk buah-buahan dan susu. Dari hasil penelitian ini juga kita dapat mengetahui msebagian besar responden yang mengasuh sendiri anak balitanya hal ini disebabkan karena pekerjaan responden sebagian besar ibu rumah tangga yang selalu ada dirumah. Responden juga memberikan makanan tambahan seperti kacang ijo dan nasi 


\section{JURNAL REGEHATAN LINGKUNGAN

pada anaknya dan mengajarkan cuci tangan tetapi tidak semua menggunakan sabun. Variabel pola asuh ini juga kita dapat mengetahui bahwa responden telah memberikan vitamin A kepada anaknya yang di lakukan di posyandu atau puskesmas. Hal inilah yang menyebabkan ada hubungan antara pola asuh dengan gizi kurang pada balita Suku Bajo dan Non Bajo di wilayah kerja Puskesmas Nambo.

Penelitian ini sejalan dengan penelitian M. Dody Izhar (2018) dengan judul pelatihanhubungan antara pengetahuan ibu dengan pola asuh makan terhadap status gizi anak di Kota Jambi. Hasilnya diketahui bahwa pengetahuan kurang baik sebanyak 26 ibu (33,3\%), pola asuh kurang baik sebanyak 47 ibu $(60,3 \%)$ dan status gizi kurang sebanyak 12 balita (15,4\%). Ada hubungan secara signifikan pengetahuan ibu dengan pola asuh makan $(p=0,001)$, dan ada hubungan secara signifikan pola asuh makan dengan status gizi anak $(p=0,022)$, berdasarkan analisis stratifikasi tidak ada perbedaan antara pengetahuan yang baik $(p=1,000)$ dan kurang baik $(p=0,208)$ dengan pola asuh makan terhadap status gizi. Penelitian ini menyimpulkan bahwa ada hubungan yang signifikan antara pengetahuan ibu dan pola asuh makan terhadap status gizi anak di Kota Jambi (11).

Penelitian ini sesuai dengan penelitian dari Aramico dkk (2016) yang menemukan ada hubungan antara pola asuh dengan kejadian gizi kurang pada balita dengan nilai $\mathrm{p}=$ 0,001.Dari hasil analisis statistikanya pada uji silang diperoleh bahwa sebagian besar rsepondennya memiliki pola asuh yang kurang baik, hal yang sama dengan penelitian ini. Dalam penelitian Aramico juga membandingkan antara dua kelompok sampel yaitu kelompok stunting dan kelompok normal dan penelitian ini juga membandingkan dua kelompok yaitu kelompok suku bajo dan non bajo. Hal ini memungkin adanya kesamaan hasil dari kedua penelitian ini (12).

\section{Hubungan Pemberian ASI Eksklusif dengan Gizi Kurang pada Suku Bajo dan Non Bajo di Wilayah Kerja Puskesmas Nambo}

Asupan gizi yang baik adalah hal penting selama 1000 hari pertama dari awal mula kehidupan anak, mulai dari rahim ibu sampai dengan tahun kedua kelahirannya.
Setelah bayi lahir pemberian ASI dapat memberikan gizi yang adekuat pada bayi untuk tumbuh dengan laju yang sesuai. ASI eksklusif diberikan sampai umur 6 bulan tanpa diberikan MP ASI (Makanan Pendamping ASI). Kandungan nutrisi pada ASI sangat berperan penting dalam perkembangan otak terutama motorik pada bayi (13).

Salah satu cara untuk meningkatkan status gizi bayi adalah dengan pemberian ASI ekslusif sampai usia 6 bulan. Pemberian ASI ekslusif pada bayi akan berdampak terhadap psikomotor, kognitif dan sosial serta secara klinis terhadap pertumbuhannya (14). Kemampuan ASI untuk membantu pertumbuhan sangat ditentukan oleh kandungan nutrisi yang terdapat dalam ASI. Kandungan ASI sangat dipengaruhi oleh asupan energi ibu. Semakin baik asupan energi ibu maka akan semakin menjamin kualitas dan kuantitas ASI. ASI mengandung makronutrien dan mikronutrien. Makronutrien yang terdiri dari karbohidrat, lemak, dan protein akan dimetabolisme oleh tubuh menghasilkan ATP dan akan digunakan untuk keperluan prosesproses dalam tubuh. Jika konsumsi energi lebih dari yang dibutuhkan tubuh maka akan disimpan dalam bentuk glikogen di hati dan otot, sehingga mempengaruhi berat badan (15).

Hasil analisis data secara statistik menunjukkan bahwa ada berhubungan pemberian ASI eksklusif dengan gizi kurang pada balita suku Bajo dan Non Bajo di wilayah kerja Puskesmas Nambo Kota Kendari tahun 2019. Berdasakan hasil penelitian yang diperoleh secara langsung melalui wawancara dan pengisian kuisioner di wilayah kerja Puskesmas Nambo menunjukan bahwa dari 80 responden yang di teliti sebanyak 34 responden yang memberikan ASI eksklusif dan 46 responden yang tidak memberikan ASI eksklusif kepada anaknya.

Penelitian ini diperoleh responden lebih banyak yang tidak memberikan ASI eksklusif kepada anaknya di bandingkan dengan yang meberikan ASI eksklusif selama 6 bulan tanpa adanya makanan tambahan. Ada beberapa alasan yang di berikan diantaranya kerena bekerja dan produksi ASI kurang tapi yang lebih banyak menjawab lebih ke produksi ASI kurang, alasan ASI kurang di antaranya tidak mengelola stres dengan baik contohnya merasa gelisah, rasa sakit atau masalah finansial, sedang hamil, 


\section{JURNAL REGEHATAN LINGKUNGAN

hal ini di sebabkan hormon kehamilan dapat menurunkan produksi ASI atau pola makan tidak sehat juga dapat menurunkan produksi ASI. Karena bayi usia 0-6 bulan tersebut tidak di berikan ASI eksklusif maka di berikan susu formula atau teh. Hal inilah yang menyebabkan adanya hubungan antara pemberian ASI eksklusif dengan gizi kurang pada balita Suku Bajo dan Non Bajo.

Penelitian ini pula sejalan dengan Olvi Sukoco dkk (2019), diperoleh nilai p 0,000 < 0,005 sehingga menunjukkan bahwa terdapat hubungan antara pemberian ASI Eksklusif dengan status gizi anak berdasarkan indeks BB/U di Wilayah Kerja Puskesmas Tateli. Hal ini menunjukan dari total 54 responden yang tidak memberikan ASI Eksklusif terdapat 22 (40,7\%) anak dengan status gizi kurang, 29 (53,7\%) gizi baik dan $3(5,6 \%)$ gizi lebih. Sedangkan dari total 24 responden yang memberikan ASI Eksklusif terdapat 23 (95,8 \%) anak dengan status gizi baik dan 1 (4,2 \%) gizi lebih (16).

Penelitian ini juga sejalan dengan Christina C. Sahalessy dkk (2019) responden yang memberikan ASI secara eksklusif sebanyak 46 responden, 46 responden memiliki anak yang dapat dikategorikan berstatus gizi baik dan tidak ada responden memiliki anak yang dikategorikan berstatus gizi kurang. Responden yang tidak memberikan ASI eksklusif pada anak yaitu sebanyak 41 responden, dari 41 responden yang tidak memberikan ASI eksklusif pada anak terdapat 37 responden memiliki anak yang dikategorikan dalam status gizi baik dan responden yang memiliki anak yang dikategorikan dalam status gizi kurang yakni 4 responden. Hasil pengujian secara statistik dengan uji Fisher's Exact didapatkan nilai $p$ yaitu 0,045, yang diartikan adanya hubungan antara pemberian ASI yang diberikan secara eksklusif dengan status gizi menurut indeks $\mathrm{BB} / \mathrm{U}(17)$.

\section{KESIMPULAN}

Ada hubungan antara pola asuh dengan gizi kurang pada balita Suku Bajo dan Non Bajo di wilayah kerja Puskesmas Nambo Kota Kendari tahun 2019 dengan p-Value 0,039 dan ada hubungan antara pemberian ASI eksklusif dengan gizi kurang pada balita Suku Bajo dan Non Bajo di wilayah kerja Puskesmas Nambo Kota Kendari tahun 2019 dengan p-value 0,000.

\section{SARAN}

1. Bagi masyarakat diharapkan masyarakat lebih memperhatikan pola asuh balita karena pada masa balita sangat memerlukan makanan yang bergizi untuk pertumbuhan dan perkembangannya dan diharapkan masyarakat mengetahui dampak dari tidak diberikannya bayi ASI eksklusif, bagi Instansi Terkait Khususnya Puskesmas Nambo.

2. Bagi institusi kesehatan, melakukan penyuluhan kesehatan dengan mengikutsertakan kader, bagian kesehatan lingkungan dan gizi, perangkat pemerintah dan lain-lain sebagai tujuan untuk meningkatkan pengetahuan masyarakat di bidang kesehatan lingkungan dan gizi. Khusunya tentang higiene sanitasi makanan dan pemberian ASI eksklusif untuk pencegahan penyakit akibat gizi dan penyakit infeksi

3. Bagi Peneliti, untuk peneliti lain dapat melakukan penelitian dengan lebih teliti serta menambahkan variabel baru atau lain untuk melihat lebih spesifik tentang apa penyebab penyakit akibat gizi.

\section{DAFTAR PUSTAKA}

1. Articles The burden of child and maternal malnutrition and trends in its indicators in the states of India: the Global Burden of Disease Study 1990 - 2017. The Burden of Child and Maternal Malnutrition and Trends in Its Indicators in the States of India: The Global Burden of Disease Study 1990-2017, 3, 855856.https://doi.org/10.1016/S23524642(19)3 0273-1

2. World Health Organization.WHO Child Growth Standards and The Identification of Severe Acute Malnutrition in Infants and Children. 2018.

3. Lestari, S. A., Pakkan, R., \& Surianto, T. S. Faktor-Faktor Yang Berhubungan Dengan Kejadian Status Gizi Balita Di Wilayah Kerja Puskesmas Mekar Kota Kendari. Program Studi Kesehatan Masyarakat Stikes Mandala Waluya Kendari. 2019;2(1), 121-133.

4. Supariasa, dkk.Penilaian Status Gizi. Penerbit Buku Kedokteran EGC. Jakarta; 2015.

5. Kementerian Kesehatan RI. Profil Kesehatan Indonesia 2018 Jakarta: Kemenkes RI.2019. 


\section{JURNAL KDSEHATAN LINGKUNGAN \\ UNIV. HALU OLEO \\ (JKL - UHO)}

6. Dinas Kesehatan Provinsi Sulawesi Tenggara.Profil Kesehatan Povinsi Sulawesi Tenggara. Tahun 2017. Kendari : Dinkes Prov. Sultra; 2019.

7. Dinas Kesehatan Kota Kendari. 2019. Data Kesehatan Kota Kendari. Kendari : Dinkes Kota Kendari;2019.

8. Pratiwi, Tiara Dwi. Hubungan pola asuh ibu dengan status gizi balita di wilayah kerja Puskesmas Belimbing Kota Padang. Jurnal Kesehatan Andalas; 2016. https:// doi.org/ 10.1080/19325037.2013.767734

9. Rapar, V. L., Rompas, S., Ismanto, A. Y.Hubungan pola asuh ibu dengan status gizi balita di wilayah kerja puskesmas ranotana weru kecamatan wanea kota manado. 2014; $1-7$.

10. Supariasa, dkk. Penilaian Status Gizi. Penerbit Buku Kedokteran EGC. Jakarta; 2015.

11. Izhar, $M$ Dody. Hubungan Antara Pengetahuan Ibu Dengan Pola Asuh Makan Terhadap Status Gizi Anak Di Kota Jambi. Jurnal Kesmas Jambi (JKMK). 2017;1(2).

12. Aramico, B., Sudargo, T., \& Susilo, J. Hubungan sosial ekonomi, pola asuh, pola makan dengan stunting pada siswa sekolah dasar di Kecamatan Lut Tawar, Kabupaten Aceh Tengah. Jurnal Gizi Dan Dietetik Indonesia (Indonesian Journal of Nutrition and Dietetics). 2016. https://doi.org/10.21927/ijnd.2013.1(3).121-130

13. Sukoco, O., Punuh, M. I., Malonda, N. S. H., Kesehatan, F., Universitas, M., \& Ratulangi, S. Hubungan Antara Pemberian Asi Eksklusif Dengan Status Gizi Anak Umur 12-24 Bulan Di Wilayah Kerja Puskesmas Tateli Kecamatan Mandolang Kabupaten Minahasa. 2019.

14. Haryono, R. Setianingsih, S. Manfaat ASI Eksklusif. Yogyakarta: Pustaka Baru;2014

15. Colby DS. Ringkasan Biokimia Harper. Jakarta, Penerbit Buku Kedokteran EGC; 2011

16. Sukoco, O., Punuh, M. I., Malonda, N. S. H., Kesehatan, F., Universitas, M., \& Ratulangi, S. Hubungan Antara Pemberian Asi Eksklusif Dengan Status Gizi Anak Umur 12-24 Bulan Di Wilayah Kerja Puskesmas Tateli Kecamatan Mandolang Kabupaten Minahasa. 2019

17. Sahalessy, C. C., Punuh, M. I., \& Amisi, M. D. Hubungan Antara Pemberian Asi Eksklusif
Dengan Status Gizi Anak Usia 12-24 Bulan Di Wilayah Kerja Puskesmas Pineleng Kabupaten Minahasa, 2019;8(6), 186-194. 